\title{
Kidney Cancer pM1 TNM Finding v6 and v7
}

National Cancer Institute

\section{Source}

National Cancer Institute. Kidney Cancer pM1 TNM Finding v6 and v7. NCI Thesaurus.

Code C63577.

Kidney cancer with distant metastasis. (from AJCC 6th and 7th Eds.) 